\title{
履歴減衰型免震部材の復元力モデルに関する研究 AN ANALYTICAL MODEL FOR SEISMIC ISOLATION DEVICES WITH HYSTERETIC DAMPING
}

\author{
菊地 優*, 北村佳 久**, 井上圭一***, 上田正生**** \\ Masaru KIKUCHI, Yoshihisa KITAMURA, Keiichi INOUE \\ and Masaiki UEDA
}

\begin{abstract}
For the purpose of accurately predicting the seismic response of an isolated building, an analytical model for seismic isolation devices with hysteretic damping is proposed. The proposed model is capable of well-predicting the force-displacement relationships of various different types of devices, high-damping rubber bearings, lead-rubber bearings, and two types of steel dampers. Seismic response analyses are conducted to study the effectiveness of both existing models and the proposed model. The responses given by the existing models are mostly conservative. This fact indicates that the proposed model can be used to evaluate the performance of isolation devices accurately and effectively.
\end{abstract}

Keywords: $\quad$ seismic isolation device, hysteretic damping, high-damping rubber bearing, lead-rubber bearing, steel damper, hysteresis model 免震部材，履歴減衰，高減衰積層ゴム，鉛プラグ入り積層ゴム，鋼材系ダンパー，復元力モデル

1.はじめに

减衰性能を有する積層ゴムアイソレータ、あるいは履歴型ダン パーで構成される免震システムを適用した建物の設計では、各免震 部材の復元力特性を適切にモデル化することが地震時応答予測にお いて不可欠となる。減衰性能を有する積層ゴムアイソレータとして は高減衰積層ゴム、鉛プラグ入り積層ゴム、滑り減衰免震部材の 3 タイプが一般的である。一方、履歴型ダンパーとしては主として鋼 材系ダンパー、鉛ダンパー、摩摖ダンパーの 3 タイプが挙げられる。 履歷減衰性能を期待するこれらの免震部材（以下、履歴減衰型免震 部材と称する）を採用した免震システムの設計では、免震部材の種 類ごとに異なる復元力モデルが使用されているのが現状である ${ }^{1}$ 。 本論文ではこの現状に着目し、免震部材の種類ごとに異なる復元力 モデルを使い分けなければならないという煩雑性を回避して、効果 的な免震システムの選択を容易とする共通の復元力モデルの提案を 目的として揭げる。なお、ここで提案する復元力モデルは、各履歴 減衰型免震部材で用いられてきた既往の復元力モデルよりも復元力 特性の良好な再現性を意図しており、各免震部材の復元力特性に共 通性を見出して簡略なモデル化を施すこととは主旨が異なる。

本論文では、初めに履歴减衰型免震部材に適用されてきた既往の
復元力モデルについて概観し、その利点・欠点を明確にする。続い

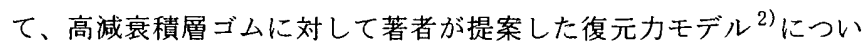
て概説し、他の履歴減衰型免震部材人の抎張を試みる。具体的には、 本研究において実験データを入手した、低弾性タイプの高減衰積層 ゴム、鉛プラグ入り積層ゴム、免震鋼棒ダンパー、免震U型ダンパー の 4 種類の履歷減衰型免震部材の荷重変形関係を再現する。最後に、 これを用いて得られる免震建物の地震応答值を、既往の復元力モデ ルによる結果との比較において考察する。

\section{2. 既往の復元カモデルに関する考察}

履歴減衰型免震部材は荷重変形関係に見られるエネルギー消費に よって减衰性能を発揮する免震部材であり、減衰性能は履歴ループ の面積から直接的に評価される。これを復元力モデルとして表現す るには、復元ガモデルと実験結果の履歷ループ面積が等価になるよ うにパラメータを設定する必要がある。エネルギー消費を履歴モデ ルで表現する最も単純な方法はバイリニアモデルであり、多くの履 歴減衰型免震部材に適用されてきた。ただし、高减衰積層ゴムや鉛 プラグ入り積層ゴムでは、せん断ひずみに依存した履歷ループ形状 の変化に対応させるために、初期剛性 $K_{1}$ 、降伏後剛性 $K_{2}$ 、降伏荷重

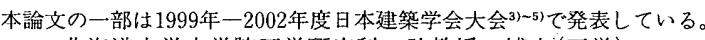

* 北海道大学大学院工学研究科 助教授・博士 (工学)

** 清水建設侏設計本部 設計長

*** 北海道大学大学院二工学研究科 助手・博士 (工学

**** 北海道大学大学院二兄学研究科教授. 工博
}

Assoc. Prof., Graduate School of Engineering, Hokkaido Univ., Dr. Eng. Manager, Design Division, Shimizu Corporation

Instructor, Graduate School of Engineering, Hokkaido Univ.,' Dr. Eng. Prof., Graduate School of Engineering, Hokkaido Univ., Dr. Eng. 


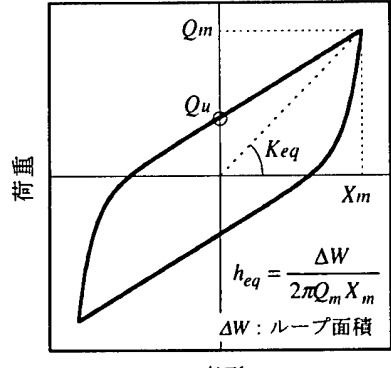

（a）パラメータの定義

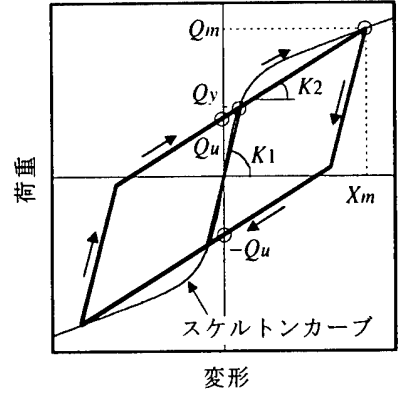

(b) 履歴則
図 1 修正バイリニアモデル

$Q_{y}$ の 3 パラメータをゴムのせん断ひずみに忘じて更新する修正バイ リニアモデルが提案され実用に供されている（図1参照）1）。

例えば、高減衰積層ゴムに適用される修正バイリニアモデルでは、

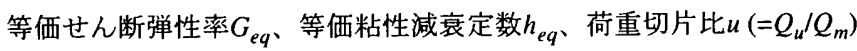
について、せん断ひずみを変数とする実験式が用意されていること が前提となる。スケルトンカーブからの除荷時の変形 $X_{m}$ と荷重 $Q_{m}$ を用い、復元カモデルの履歴ループ面積を実験結果と等価にする条 件よりバイリニアモデルの各パラメータを以下のように設定する。

$$
\begin{aligned}
& K_{1}=\frac{2 u-(1-u) \pi h_{e q}}{2 u-\pi h_{e q}} K_{e q} \\
& K_{2}=(1-u) K_{e q} \\
& Q_{y}=\frac{u Q_{m} K_{1}}{K_{1}-K_{2}}
\end{aligned}
$$

ここで、K $K_{e q}$ は積層ゴムの等価剛性であり、ゴムの総厚 $H_{r}$ および ゴムの断面積 $A_{r}$ を介した相似則が成立するとして、ゴムの等価せん 断弾性率 $G_{\text {eq }}$ から(4) 式によって求めることができる。

$$
K_{e q}=\frac{G_{e q} A_{r}}{H_{r}}
$$

（1）～(3) 式の主旨は、勾配を $K_{2}$ とし荷重切片の正負（図 1 (b) の $\left.\pm Q_{u}\right)$ をそれぞれ通る 2 直線で囲まれる面積を初期剛性 $K_{1}$ を(1) 式 で求めることで実験結果の履歷ループ面積と等価にすることにある。 しかし、 $G_{e q}, h_{e q}, u$ の組み合わせによっては $K_{1}$ が不定となる場合 があり、何らかの条件緩和が必要となる。

本論文では、図 2 に形状を示した低弾性 (G4) タイプの高堿衰積層 ゴムの実験結果 ${ }^{6)}$ (図 3 参照) に対して修正バイリニアモデルの適用 を考える。初めに、実験結果から各ひずみレベルにおける $G_{e q}, h_{e q}$, $u$ を求め、データの散布状況から累乗式あるいは多項式をあてはめ 最小 2 乗法によって表 1 に示す実験式を得た。例として $G_{e q}, h_{e q}$ の 回帰状況について散布データ、回帰式による結果を比較して図 4 に 示す。この実験式を用いて (1) 式から $K_{1}$ を評価した結果を図 5 に太 線 $(1.0 u)$ で示す。せん断ひずみ $\gamma$ が 2.0 を超えるあたりから $K_{1}$ は 不定となるが、これは $K_{1} \rightarrow \infty$ としてもバイリニアモデルでは $h_{e q}$ を 等価にする条件を満足させる所要の履歴ループ面積を確保できない ことが原因である。 $K_{1}$ が不定となる問題を回避するためには、例え ば、以下のような方法が考えられる。

(1) $h_{e q}$ を等価にする条件を無視して $K_{1}$ に制限を設ける。

(2) $h_{e q}$ を等価にする条件を重視して $u$ の条件を緩和する。

(3) (1)と(2)を併用する。

以上は履歴ループの形状がバイリニア型とはならない状況において
・本体ゴム：高减衰ゴム (G4)

・被覆ゴム：天然ゴム（厚さ $10 \mathrm{~mm}$ )

- 積層部 :

ゴム: $2.4 \mathrm{~mm} \times 33$ 層

銈板: $3.2 \mathrm{~mm} \times 32$ 層

ゴム総厚 : $79.2 \mathrm{~mm}$

- 形状係数 : $\mathrm{S} 1=40, \mathrm{~S} 2=5.05$

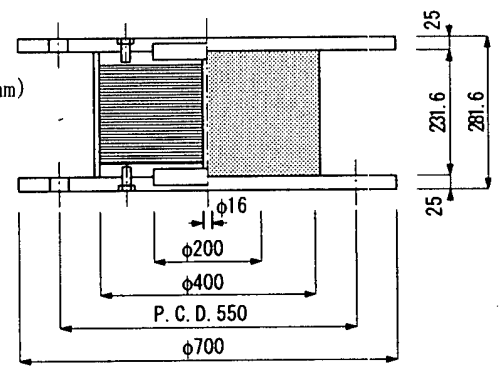

図 2 高减衰積層ゴム試験体の形状

\section{- 実験条件}

振動数: $0.01 \mathrm{~Hz}$

面压 : $9.81 \mathrm{~N} / \mathrm{mm}^{2}\left(100 \mathrm{kgf} / \mathrm{cm}^{2}\right)$ せん断ひずみ：士25〜325\%

(変形 : $\pm 19.8 \sim 257.4 \mathrm{~mm})$

各ひずみ 4 サイクル加力

図は 3 サイクル目を採用

実験時室温 : $20^{\circ} \mathrm{C}$

図 3 高減衰積層ゴムの 実験結果

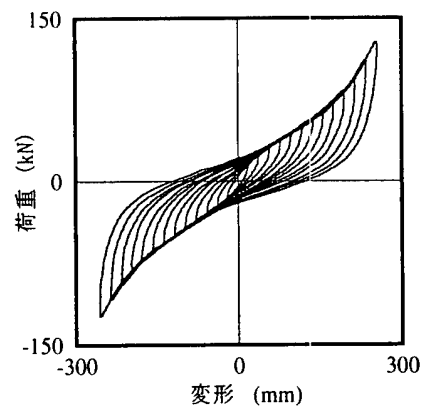

表 1 高减衰積層ゴムの復元力パラメータ評価式

$\begin{aligned} G_{e q} & =0.302 \gamma^{-0.461}\left(\mathrm{~N} / \mathrm{mm}^{2}\right) \quad(\gamma \leqq 1.35) \\ & =0.417-0.165 \gamma+0.0454 \gamma^{2}-0.00117 \gamma^{3}(1.35<\gamma \leqq 3.25) \\ h_{e q} & =0.196-0.0474 \gamma+0.0231 \gamma^{2}-0.00475 \gamma^{3} \quad(\gamma \leqq 3.25) \\ u & =0.329+0.0156 \gamma-0.0357 \gamma^{2}+0.00459 \gamma^{3} \quad(\gamma \leqq 3.25) \\ n & =1.0 \quad(\gamma \leqq 1.68) \\ & =2.60-2.30 \gamma+0.804 \gamma^{2}(1.68<\gamma \leqq 3.25) \\ \gamma & \text { はゴムのせん断ひずみ } \quad\left(\gamma=X / H_{r}\right) \text { とする。 }\end{aligned}$
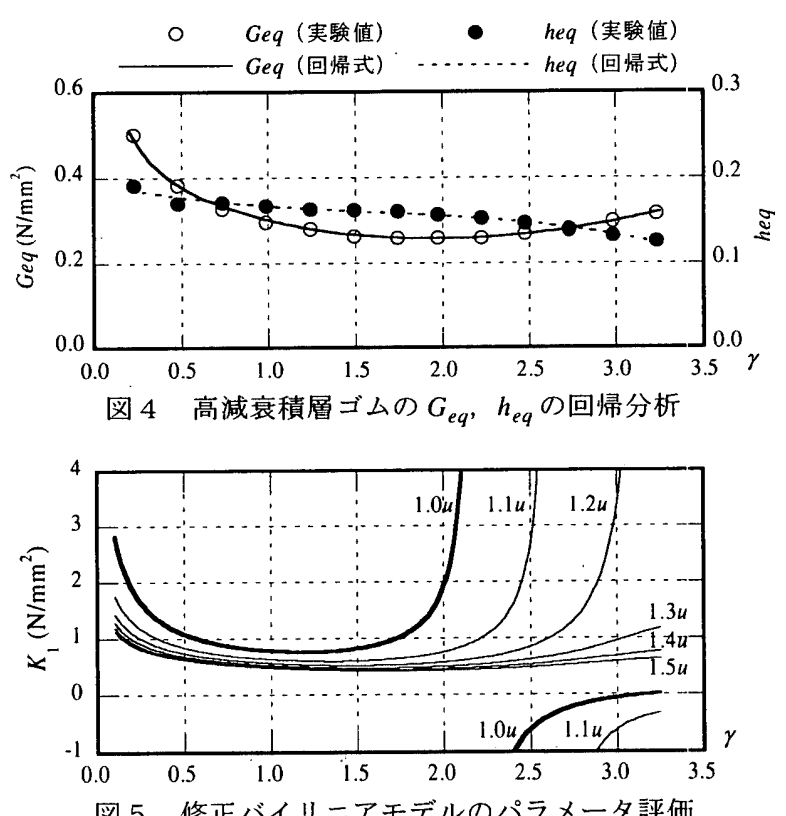

図 5 修正バイリニアモデルのパラメータ評佃

も、これを適用することで生じた問題である。(1)方法では堿哀定 数が過小評価されることから安全側の評価になると言えるが、一方 で免震部材の性能を十分に評価していないという欠点があると言え る。図 5 には(2)の方法に従ってuの条件を緩和させた場合として、表 1 の実験式で得られる $u$ を $1.1 \sim 1.5$ 倍の範囲で変化させたときに (1) 式から得られる $K_{1}$ を合わせて示している。 $u$ を実験式の 1.3 倍ま 
で緩和することで $K_{1}$ の不連続領域を一応回避できるが、あるいは (2)のをすべてのひずみ領域で一律に適用すると、不自然な履歴 ループ形状となる可能性があるため、(1)と(2)を併用することが現実 的である。パラメータを变形（せん断ひずみ）に依存させて更新す ることは、広い変形領域で免震部材の堿衰性能を適切に評価できる 利点を有するが、条件の緩和措置が必要であることはバイリニアモ デルの適用限界が露呈した結果と言える。

\section{3. 高減衰積層ゴムの復元カモデル}

\section{1 復元力特性の検討}

著者は修正バイリニアモデルに関する上述の問題点を解決すべく、 履歴ループ形状を剛性を操作する $Q_{1}$ と履歴ループ面積を操作する $Q_{2}$ に分離して評価し、荷重変形関係を(5)〜 (7) 式のように表現する 復元カモデルを $\mathrm{G} 6$ タイプの高減衰積層ゴムに対して提案した ${ }^{2)}$ 。

$$
\begin{aligned}
& Q=Q_{1}+Q_{2} \\
& Q_{1}=\frac{1}{2}(1-u) Q_{m}\left\{x \pm|x|^{n}\right\} \\
& Q_{2}= \pm u Q_{m}\left\{1-2 e^{-a(1 \pm x)}+b(1 \pm x) e^{-c(1 \pm x)}\right\}
\end{aligned}
$$

(複合同順, $\dot{X}>0$ のとき,$+ \dot{X}<0$ のときー) ここで、 $x$ は変形の無次元量 $\left(=X / X_{m}\right)$ であり、 $a, b, c, n$ は履歴ルー プ形状を操作するパラメータである。

図 6 に(5)〜 (7) 式で表現される履歴ループ形状を無次元量にして 示す。パラメータの操作によって図 3 の実験結果に見られるような 低ひずみ領域での紡鍾形から高ひずみ領域でのハードニングに至る 履歷ループ形状の特徵が表現されていることがわかる。nはハード ニングを表現するパラメータであり、n>1とすることで徐々にハー ドニングが強くなる。cは図 6 の (7) 式の曲線における極大点（荷重 正側)、極小点 (荷重負側) の位置を操作するパラメータであり、(5) 〜 (7) 式の性質から $c=6 \sim 7$ の範囲で概水高減衰積層ゴムの復元力特 性を表現できる7)。 $a ， b$ について修正バイリニアモデルと同様に 履歴ループ面積を実験結果と等価にする条件を導入することで、(8) （9）式から算出する。ただし、aはスケルトンカーブからの除荷時 の剛性に大きく寄与することから、 $a$ をあるひずみの值で頭打ちと し、それ以降は $b$ によって面積を等価にする手順が妥当である。

$$
\begin{aligned}
& \frac{1-e^{-2 a}}{a}=\frac{2 u-\pi h_{e q}}{2 u} \\
& b=c^{2}\left[\frac{\pi h_{e q}}{u}-\left\{2+\frac{2}{a}\left(e^{-2 \dot{a}}-1\right)\right\}\right]
\end{aligned}
$$

本論文では、これを図 3 に実験結果を示したG4タイプの高减衰積 層ゴムに適用してみる。図 7 に(3)の方法 $\left(u^{\prime}=1.1 u\right.$ 、および $K_{1} \leqq 10 K_{2}$ の併用)を適用した場合の修正バイリニアモデルと、(5)〜 (7) 式の提 案モデルの履歴ループの比較を示す。提案モデルの適用にあたり、 文献》索照して回帰したnの評価式を前掲の表 1 に示寸。なお、提 案モデルについては、 $\gamma \leqq 1.5$ では $b=0$ として (8) 式のみを用い、 $\gamma>$ 1.5 において $c=6$ として (9) 式を適用した。図 7 によば(3)の方法で パラメータが不定とならずに評価できたとしても、バイリニア型の 履歴ループ形状ではひずみの大きな領域では実験結果を良好に再現 することができない。一方、提案モデルはあらゆるひずみ領域にお いて実験結果を良好に再現していることがわかる。
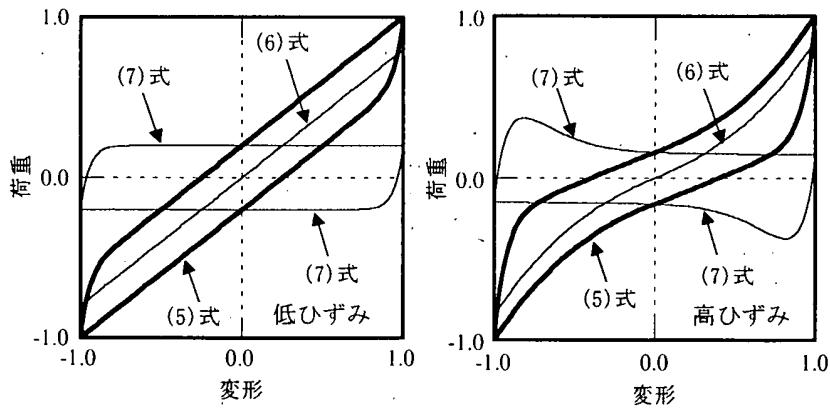

図 6 提案復元力モデルの無次元化ループ.
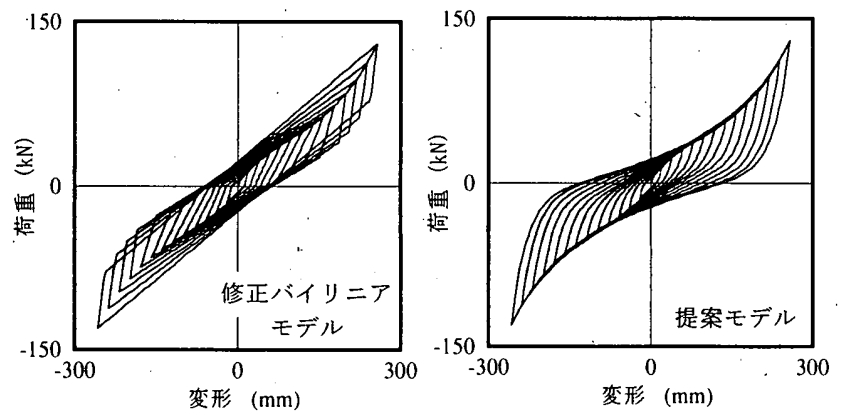

図 7 高減衰積層ゴムの解析結果

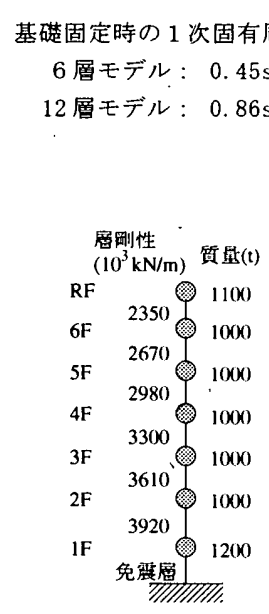

(a) 6 層モデル

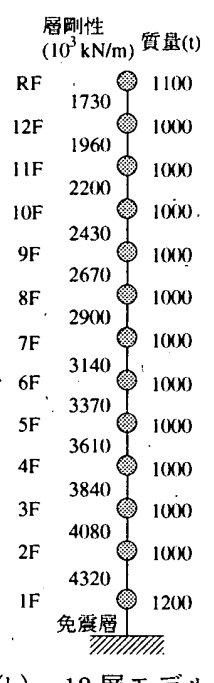

(b) 12 層モデル
図 8 免震建物の振動モデル

なお、ここで試みた荷重変形関係の再現は図 3 の実験結果を対象 としており、実験条件と異なる面圧、載荷速度、温度等が復元力特 性に及ぼす変動は考慮していない。これらの要因が復元力特性に及 ぼす影響については $G_{e q}, h_{e q}$ の変動として実験データが整理されて いる ${ }^{6)}$ 。よって、実験条件と異なる状況での提案モデルの適用には、 各要因による $G_{e q}, h_{e q}$ の変動の有無を実験式に考慮する必要がある。 また、大変形経験後の剛性回復現象については 2 段階のスケルトン カーブを用意し最大経験ひずみによってこれらを使い分ける方法が 提案されており 2)、修正バイリニアモデル、提案モデルの双方に適 用可能である。しかし、図 3 の実験結果は時間を経過させた複数回 の加力実験ではないことから、本論文ではこれを考慮していない。

\section{2 地震応答解析による検討}

復元力モデルの違いによる免震建物の地震応答值の変化を把握す るために、地震応答解析による検討を行う。建物モデルとしては 6 
層および 12 層の $\mathrm{RC}$ 造建物を想定し、図 8 に示す振動モデルを作成 した。上部構造は弾性とし、基礎固定時に建物高さ（m）に 0.02 を 乗じた值が 1 次固有周期（s）になるような直線分布の層剛性を与 え、减衰は基礎固定時の 1 次固有振動数に対して $2 \%$ の剛性比例型减 衰とした。免震層に位置するせん断ばねに対して、前述の各種復元 カモデルを適用した。

入力地震動は図 9 に示す BCJ-L2 とした。解析時間は 120 秒、時間 刻みは 0.005 秒とし、数值積分はNewmark- $\beta$ 法 $(\beta=0.25)$ を用いた。 以上のような解析条件のもとで、以下の 2 種類の検討を行った。 1）入力地震動の原波形を入力して各階の応答加速度分布を見る。

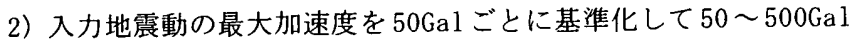
の範囲で変化させて入力した場合の入カレベルと免震層の最大 応答変位の関係を見る。

なお、2)の検討では、本論文で対象とする免震部材の復元力モデル 評価パラメータの実験式の適用範曲、あるいは併用する免震部材の 限界ひずみ ${ }^{8)}$ を超えた時点で解析を打ち切った。

図 3 に実験結果を示したG4タイプの高减衰積層ゴムのみで構成さ れる免震システムを考え、建物規模に応じて積層ゴムのサイズと台 数を以下のように設定した。ゴム総厚はいずれも $200 \mathrm{~mm}$ とした。

・ 6 層モデル : $1000 \phi \times 16$ 台

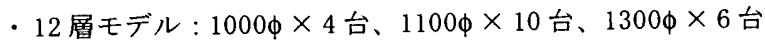

適用した復元力モデルは以下に示すようにパラメータ不定領域に 対する対処方法を 3 通りに変えた修正バイリニアモデルと提案モデ ルの合計 4 種類であり、いずれも表 1 の評価式を用いた。

・修正バイリニアモデル (1)の方法, $\left.K_{1} \leqq 10 K_{2}\right)$

・修正バイリニアモデル (3)の方法, $u^{\prime}=1.1 u$ と $K_{1} \leqq 10 K_{2}$ の併用)

・修正バイリニアモデル (3)の方法, $u^{\prime}=1.2 u$ と $K_{1} \leqq 10 K_{2}$ の併用)

・提案モデル

図 10 (a)に示寸最大加速度分布については、6 層モデルでは復元 カモデルの差異は小さいが、12層モデルでは修正バイリニアモデル の結果が提案モデルのそれよりも上回り、最下階と最上階において その傾向が顕著に現れる。修正バイリニアモデルにおいてパラメー タが不定となる以前のひずみ領域では両復元力モデルの減衰定数は 同じであり、両者の違いは履歴ループ形状のみである。大きな相違 点はスケルトンカーブからの除荷時の剛性であり、提案モデルのよ うに刻々と剛性を変化させるか、修正バイリニアモデルのように初 期剛性により同じ剛性を保持させるかの違いである。(1)の方法は荷 重切片比の条件を緩和していないことにより、他よりも初期㴊性が 大きく評価される。一方、(3)の方法では、荷重切片比の条件緩和を 大きくするに従い初期剛性は小さく評価される。図 10 (a)に見られ るように最下階と最上階で顕著となる加速度分布の差は、以上のよ うな復元力モデルの除荷時の剛性評価の差が免震建物の 2 次以上の 振動モードの励起状態の違いとして現れたものと考えられる。高減 衰積層ゴムに対する修正バイリニアモデルでは、初期剛性は履歴 ループ面積を等価にする条件から決定され、実験結果における剛性 を直接評価していない。したがって、実際の履歷ループ形状がバイ リニア型とはならない状況では、初期剛性が実験結果を反映できな い可能性がある。また、条件の緩和措置が加速度応答に大きく影響 を及ぼすことから、緩和措置の適用には十分な注意を要する。

続いて、図 10 (b)に応答加速度分布に差が見られた 12 層モデルに

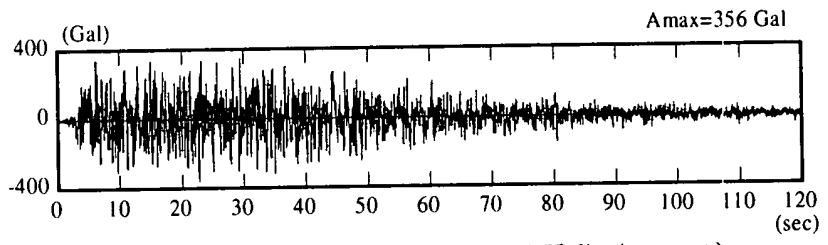

図 9 地震応答解析に用いた入力地震動 (BCJ-L2)
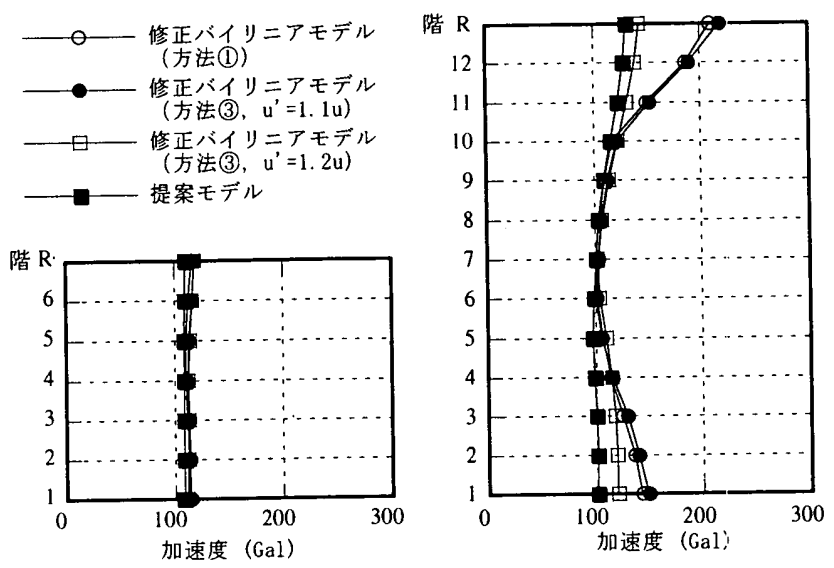

（a） 原波形入力時の応答加速度分布

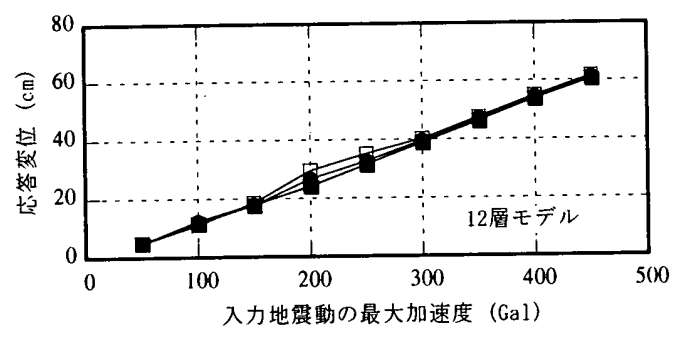

（b）入力地震動レベルと免震層最大応答变位の関係

図 10 高减衰積層ゴムを用いた建物モデルの最大応答値

おける入力地震動レベルと免震層の最大忘答変位の関係を示す。両 復元カモデルの結果はほぼ同じであり、応答加速度分布に見られた 程の差異はない。これはいずれの復元力モデルにおいても履歴ルー プ面積をほぼ同じく評価していることによると考えられる。

\section{4. 鉛プラグ入り積層ゴムの復元力モデル}

\section{1 復元力特性の検討}

鉛プラグ入り積層ゴムは鉛プラグとゴムの複合構造であり、高堿 衰積層ゴムのようにゴムのせん断ひずみ一せん断応力度の関倸を相 似則から(4)式のように任意の形状に拡幅できない。ゴム径と鉛プラ グ径の組み合わせは、ある範囲において任意である。特定の形状に 対する提案モデルの適用は高减衰積層ゴムの場合と同様に可能であ るが ${ }^{2)}$ 、すべての組み合わせについて実験結果を分析することは現 実的ではない。現状では、修正バイリアモデルの適用を前提として 実験データの分析·整理が行われている。そこで、任意のゴム径、鉛 プラグ径に対応できるように、修正バイリニアモデルのパラメータ 評価式 ${ }^{9)}$ を用いて提案モデルを抬張する。よって、拉張に先立ち文 献 $^{9)}$ に記載されている修正バイリニアモデルについて概説する。

鉛プラグ入り積層ゴムは履歴ループ形状がバイリニア型に近いこ とを出発点として、 $K_{1}, K_{2}, Q_{u}$ の 3 パラメータが (10)〜 (12) 式のよ うに直接的に評価される。 
表 2 鈶プラグ入り積層ゴムの復元カパラメータ評洒式 ${ }^{9)}$

$\begin{aligned} G_{r} & =0.392\left(\mathrm{~N} / \mathrm{mm}^{2}\right)(\mathrm{G} 4) & C_{K} & =0.779 \gamma^{-0.43}(\gamma<0.25) \\ & =0.539\left(\mathrm{~N} / \mathrm{mm}^{2}\right)(\mathrm{G} 6) & & =\gamma^{-0.25}(0.25 \leqq \gamma<1.0) \\ \alpha & =0.588\left(\mathrm{~N} / \mathrm{mm}^{2}\right)(\mathrm{G} 4) & & =\gamma^{-0.12}(1.0 \leqq \gamma<2.5) \\ & =0.883\left(\mathrm{~N} / \mathrm{mm}^{2}\right)(\mathrm{G} 6) & C_{Q} & =2.036 \gamma^{0.41}(\gamma \leqq 0.1) \\ \sigma_{p b} & =8.33\left(\mathrm{~N} / \mathrm{mm}^{2}\right) & & =1.106 \gamma^{0.145}(0.1<\gamma<0.5) \\ \beta & =13(\mathrm{G} 4) & & =1.0(\gamma \geqq 0.5) \\ & =10(\mathrm{G} 6) & \gamma \text { は } & \end{aligned}$

\section{実験条件 \\ 載荷速度 : $15 \mathrm{~mm} / \mathrm{sec}$ 面圧 : $11.8 \mathrm{~N} / \mathrm{mm}^{2}\left(120 \mathrm{kgf} / \mathrm{cm}^{2}\right)$ せん断ひずみ： $\pm 10 〜 250 \%$ (変形 : $\pm 20.4 \sim 510 \mathrm{~mm}$ ) 各ひずみ 4 サイクル加力 実駼時室温 : $26^{\circ} \mathrm{C}$}

図 12 鉛プラグ入り積層ゴム の実験結果

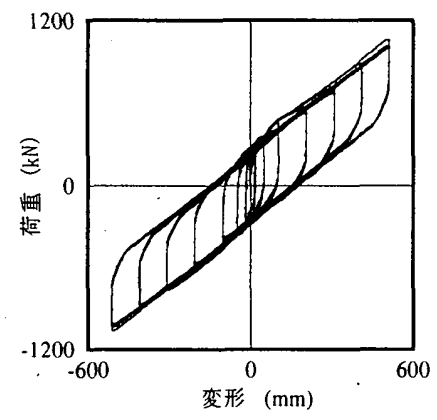

初めに、降伏後剛性 $K_{2}$ がゴムと鉛プラグのせん断剛性の和として (10)式より評価される。

$$
K_{2}=C_{K}\left(\frac{G_{r} A_{r}}{H_{r}}+\frac{\alpha A_{p}}{H_{r}}\right)
$$

ここで、 $C_{K}$ はひずみ依存性によるせん断剛性の修正係数、 $G_{r}$ はゴ ムのせん断弹性率、 $A_{r}$ 、はゴムの断面積、 $A_{p}$ は鉛プラグの断面積、 $\alpha$ は鉛プラグの見かけのせん断弾性率、 $H_{r}$ はゴムの総厚である。

初期剛性 $K_{1}$ は $K_{2}$ の倸数倍として (11) 式のように評価される。

$$
K_{1}=\beta K_{2}
$$

さらに、荷重切片 $Q_{u}$ が(12)式のように評価される。

$$
Q_{u}=C_{Q} \sigma_{p b} A_{p}
$$

ここで、 $C_{Q}$ はひずみ依存性による荷重切片の修正係数であり、 $\sigma_{p b}$ は鉛の降伏せん断応力度である。

（10）（12）式の適用にあたっては、表 2 に示す評価式が具体的に 提示されている ${ }^{9)}$ 。この中で修正係数 $C_{K}, C_{Q}$ の実験式は、ت゙ム径 $\phi 600 \sim \phi 1300$ 、鉛プラグ径 $\phi 100 \sim \phi 260$ 、ゴム総厚 $139 \sim 204 \mathrm{~mm}$ の範 囲にある合計13種類の鉛プラグ入り積層ゴムの加力実験データをも とに、せん断ひずみ $100 \%$ 基準ひずみとし、この時の降伏後剛性お よび荷重切片に対する変動量を回帰して得られたものである。

さらに、荷重切片 $Q_{u}$ からバイリニアモデルの降伏荷重 $Q_{y}$ への変 換は(13) 式を用いる。

$$
Q_{y}=\frac{K_{1}}{K_{1}-K_{2}} Q_{u}
$$

提案モデルの適用にあたっては、(14) 式で評価される修正バイリニ アモデルの等価粘性減衰定数 $h_{e q, b l}$ と等価になる条件を導入する。す なわち、 $h_{e q, b l}$ を(8) 式の $h_{e q}$ と置き換えて $a$ を評価する。

$$
h_{e q, b l}=\frac{2}{\pi} \frac{Q_{u}}{Q_{m}}\left\{1-\frac{Q_{u}}{\left(K_{1}-K_{2}\right) X_{m}}\right\}
$$

ここで、 $X_{m}, Q_{m}$ はスケルトンカーブからの除荷時の変形および荷 重である。また、後述の図12に示すように実験結果では八ードニン グが見られないことから、(6)式では $n=1 ，(7)$ 式では $b=0$ とする。

図11の鉛プラグ入り積層ゴムに対して加力実験を行った結果を図 12に示す。また、修正バイリニアモデルと提案モデルに対して図 12
・本体ゴム：天然ゴム (G4)

被覆ゴム: 天然ゴム（厚さ $10 \mathrm{~mm}$ )

・鉛プラグ径 : $200 \mathrm{~mm}$

積層部 :

ヨ゙ム: $6.0 \mathrm{~mm} \times 34$ 層

鋼板: $3.1 \mathrm{~mm} \times 33$ 層

ت゙ム総厚 : $204 \mathrm{~mm}$

形状係数: $\mathrm{S} 1=41.7, \mathrm{~S} 2=4.9$

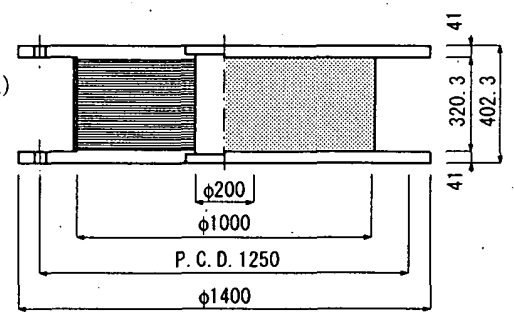

図 11 鉛プラグ入り積層ゴム試験体の形状
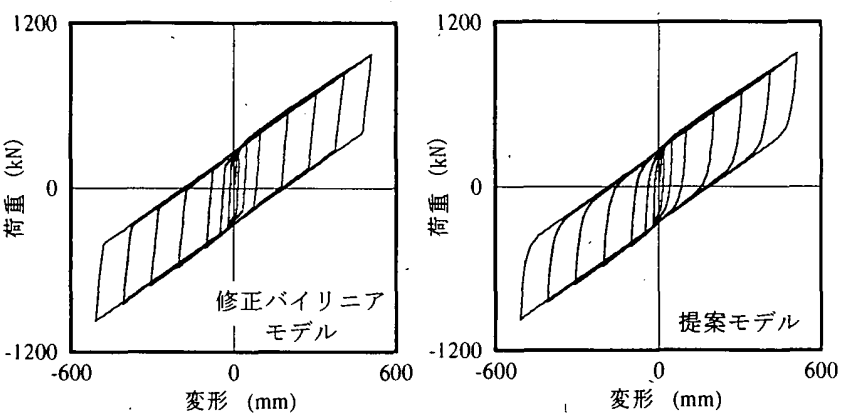

図 13 鉛プラグ入り積層ゴムの解析結果
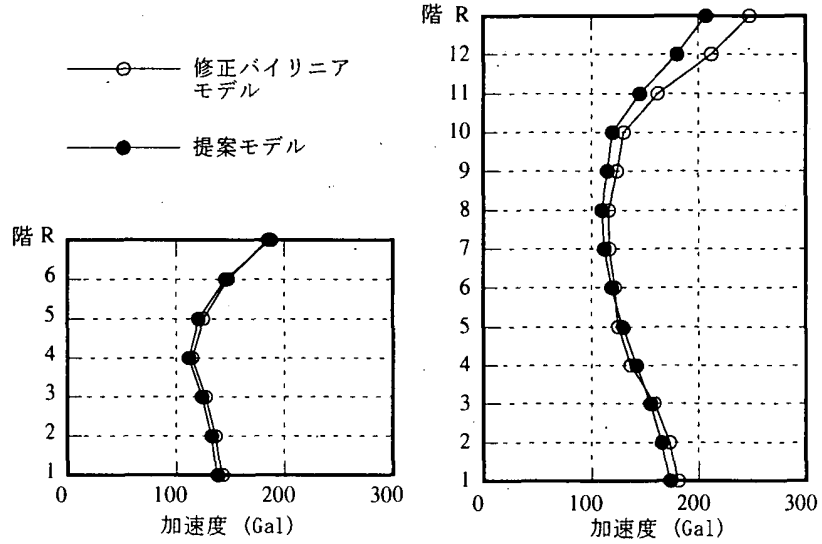

（a）原波形入力時の応答加速度分布

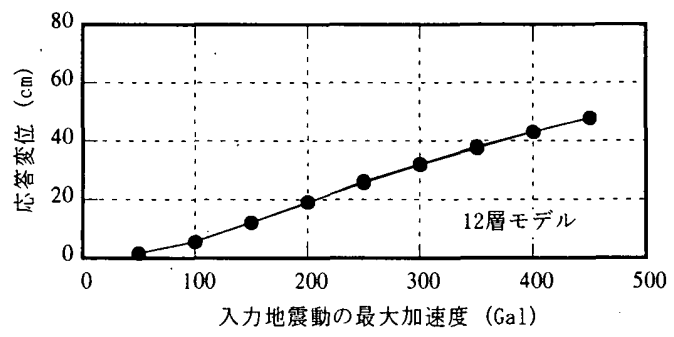

（b）入力地震動レベルと免震層最大応答変位の関係

図 14 鉛プラグ入り積層ゴムを用いた建物モデルの最大応答値

と同じ変形履歴を与えた解析結果を図13に示す。なお、表 2 の評価 式は $15^{\circ} \mathrm{C}$ を基準としていることから、実験結果と条件を合わせるた めにいずれの解析も文献 ${ }^{10)}$ に従って $K_{2}, Q_{u}$ の温度補正を行ってい る。鉛プラグ入り積層ゴムの履歴ループ形状は本来的にバイリニア 型に近いことから、修正バイリニアモデルにおいても実験結果は良 好に表現されているが、提案モデルはバイリニアモデルの角がなめ らかになった分、実験結果により近い履歷ループ形状となっている。

\section{2 地震応答解析による検討}

地震応答解析による検討では、前述の図 8 に示した建物モデルに 対して鉛プラ.グ入り積層ゴムのみで構成される免震システムを考え、 
積層ゴムのサイズと台数を以下のように設定した。

・ 6 層モデル : $800 \phi$ （ゴム総厚 $200 \mathrm{~mm}$, 鉛プラグ径 $150 \mathrm{~mm}$ ） × 16 台 ・ 12 層モデル : $900 \phi （ コ ゙ ム$ 総厚 $200 \mathrm{~mm}$, 鉛プラグ径 $170 \mathrm{~mm} ） \times 20$ 台 ゴムのせん断弾性率は $\mathrm{G}=0.392 \mathrm{~N} / \mathrm{mm}^{2}(\mathrm{G} 4)$ とし、表 2 に示される評 価式に従って復元力モデルのパラメータを設定した。

図14k地震応答解析結果を示す。原波形入力時の最大応答加速度 分布では、 6 層モデルでは両復元力モデルによる差は僅かであるが、 12層モデルでは修正バイリニアモデルの結果が提案モデルのそれを

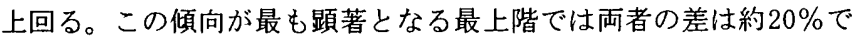
ある。鉛プラグ入り積層ゴムの場合、両復元力モデルはすべてのひ ずみレベルにおいて減衰定数を同じに評価し、両者の違いは履歴 ループ形状にある。特に図13に示した両復元力モデルの履歷ループ 形状は高減衰積層ゴムの場合と比較して実験結果との差はいずれも 小さく、両者の違いはスケルトンカーブからの除荷時の剛性のみに ある。除荷直後の剛性は提案モデルの方が大きいことから、単純に 初期剛性の大小が応答加速度の差と関連づけられるものではなく、 これを一定とするか変化させるかという剛性変化に対する扱いの違 いが同図に見られるような応答加速度分布の差をもたらしたと考え られる。一方、12層モデルにおける入力地震動レベルと免震層の最 大応答変位の関係では、高减衰積層ゴムと同様に両復元カモデルと もほぼ同じであり、答加速度分布のような差異は見られない。

\section{5. 免震鋼棒ダンパーの復元カモデル}

\section{1 復元力特性の検討}

免震銅棒ダンパーの復元力特性は、通常、バイニリアモデルが用 いられる。高減衰積層ゴムや鉛プラグ入り積層ゴムのように変形に 依存したパラメータの更新は行わなず、あらかじめ想定した変形に おける履歴ループ形状に合わせてパラメータを設定することが多い。 したがって、地震応答解析において想定変形量と異なる応答值が生 じた場合には、実挙動との差が生じる可能性がある。免震鎆棒ダン パーに対して (5) 〜 (7) 式の提案モデルを適用するには、高减衰積層 ゴムのモデル化で用いた手法を適用して、あらかじめ実験結果から 等価剛性、等価粘性減衰定数、荷重切片比についてダンパーの変形

表 3 免震鋼棒ダンパーの復元カパラメータ評価式
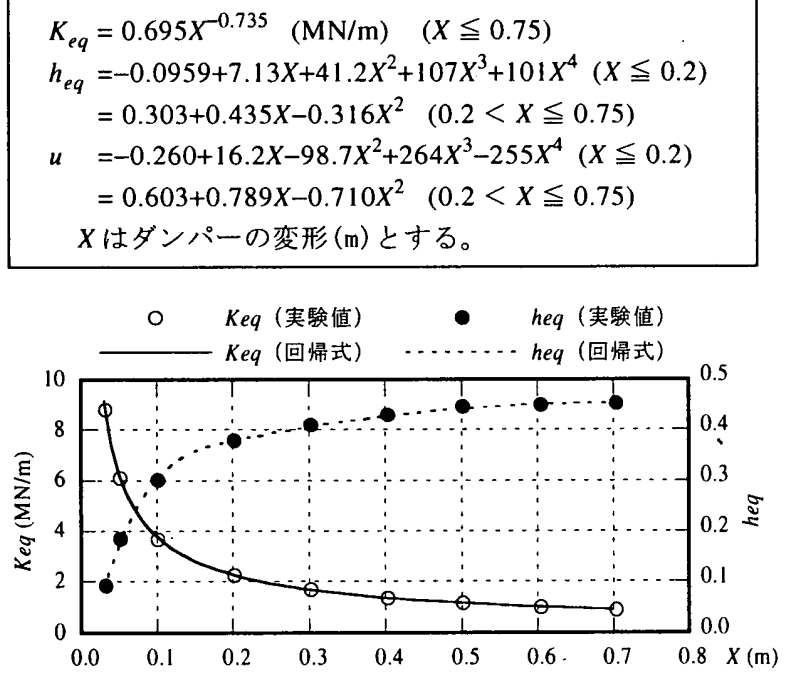

図 17 免震鋼棒ダンパーの $K_{e q}, h_{e q}$ の回帰分析
量を変数とする実験式を用意しておくことを前提とする。

本論文では図 15 に形状を示す免震鋼棒ダンパー ${ }^{11)} に$ 対して、提 案モデルの適用を試みる。同図のダンパーは90фの銅棒 (SCM415)を 半径 $365 \mathrm{~mm}$ でループ状に加工したものであり、鋼棒の上下端は回転 を拘束してベースプレートに固定されている。図16に加力実験より 得られた荷重変形関係 ${ }^{12)}$ を示す。各方向ともほぼ同様の紡鍾形の履 歴ループ形状を示しており、エネルギー吸収能に富んだ復元力特性 となっている。免震鋼棒ダンパーの復元力特性は鋼棒の一軸引張試 験結果とは異なり、その幾何学的形状により鋼棒の降伏領域が徐々 に広がっていくことから、明確な降伏荷重を定義することは困難で ある。この復元力特性をバイリニアモデルに置換する際つ降伏荷重 は、履歴ループ形状をバイリニア型に近似させるためのーパラメー タとしての位置付けに過ぎないと言える。

図 16 の実験結果を回帰分析することで等価剛性 $K_{e q}$, 等価粘性减 衰定数 $h_{e q}$, 荷重切片比uに関する実験式を表 3 のように得た。回䚻 分析の方法は高减衰積層ゴムの場合と同様であるが、ここではダン パー単体を対象とすることから各実験式の変数はダンパーの変形量 とし、A方向の結果を代表させた。図 $17 に K_{e q}, h_{e q}$ の回㷌状況につ いて散布データ、回帰式による結果を比較して示す。提案モデルの
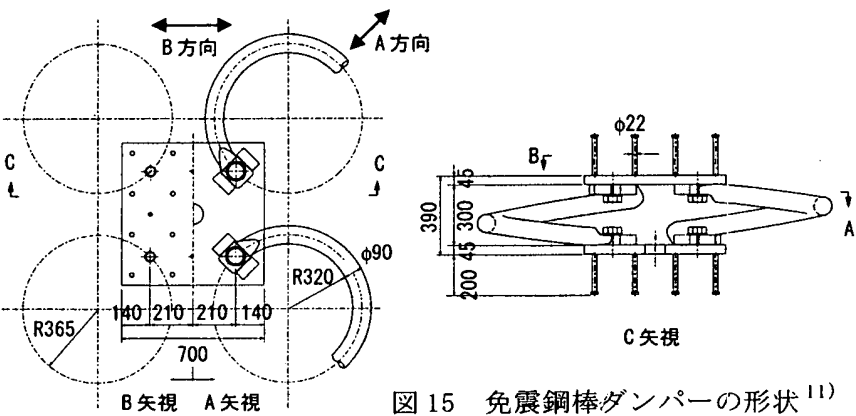

図 15
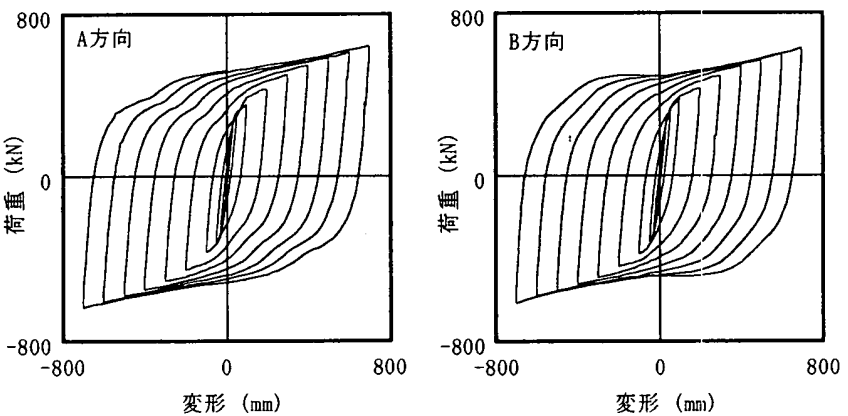

図 16 免震鋼棒ダンパーの実験結果
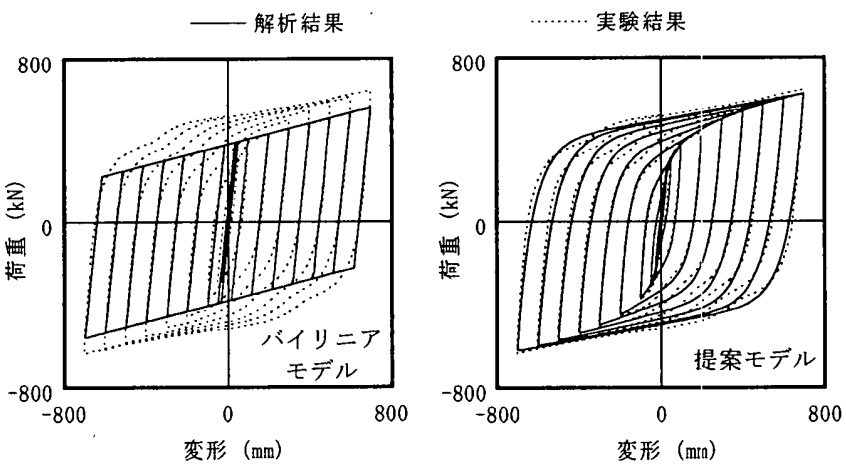

図 18 免震鏯棒ダンパーの解析結果 

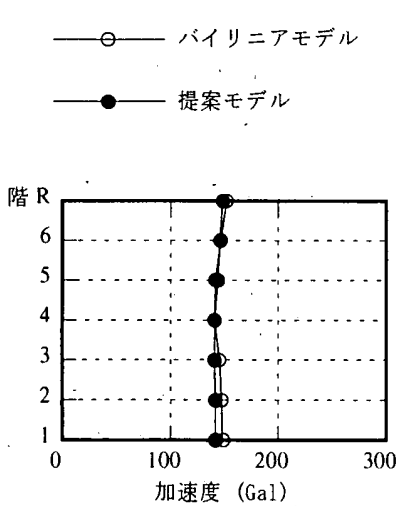

(a) 原波形入力時の応答加速度分布

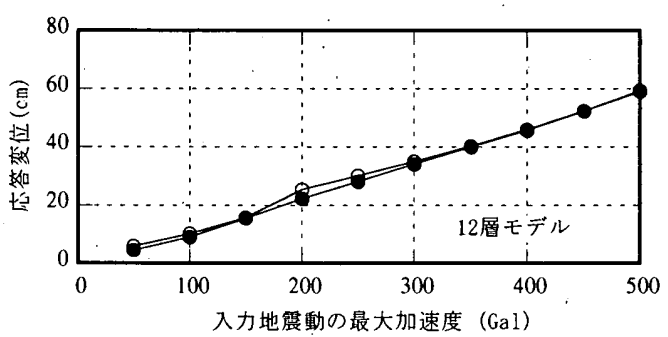

（b）入力地震動レベルと免震層最大応答変位の関係

図 19 免震鋼棒ダンパーを用いた建物モデルの最大応答値

適用にあたり、ハードニングが見られないことから鉛プラグ入り積 層ゴムの場合と同様に(6)式では $n=1 ;(7)$ 式では $b=0$ とし、 $a$ のみで 履歴ループ形状を表現できると判断した。

バイリニアモデルと提案モデルに対して図16の加力実験と同じ変 形履歴を与えて得られた解析結果を実験結果と比較して図 18 に示 す。比較に用いた実験結果は $\mathrm{A}$ 方向の結果である。また、バイリニ アモデルのパラメータは変形量 $300 \mathrm{~mm}$ のときの履歷ループ形状に合 うように設定している。両者を比較すると、提案モデルはすべての 変形領域で実験結果を良好に再現していることがわかる。

\section{2 地震応答解析による検討}

通常、免震銅棒ダンパーを用いた免震システムでは、免震鋼棒ダ ンパーが降伏変形に至る以前の減衰を補償するために鉛ダンパーと 併用されることが多い。本論文では復元力モデルによる応答の差異 を明確にする目的から、図 8 の建物モデルに対して天然ゴム系積層 ゴムと図15の免震鋼棒ダンパーのみで構成される兔震システムを考 え、以下のように積層ゴムのサイズとダンパーの台数を設定した。 ・6 層モデル：天然ゴム系積層ゴム $800 \phi （ コ ゙ ム$ 総厚 $156 \mathrm{~mm} ） \times 16$ 台

\author{
ダンパー×6 台 \\ ・12.層モデル : 天然ゴム系積層ゴム $900 \phi$ (ゴム総厚 $177 \mathrm{~mm}) \times 20$ 台 \\ ダンパー×10台
}

天然ゴム系積層ゴムのせん断弾性率はいずれも $\mathrm{G}=0.343 \mathrm{~N} / \mathrm{mm}^{2}$ (G3.5) とした。天然ゴム系積層ゴムは線形とし、ダンパーのみにバ イリニアモデルあるいは提案モデルの復元カモデルを適用した。

図 19 に地震応答解析結果を示す。最大応答加速度分布について は、6 層モデルにおける両復元力モデルの差は僅かであるが、12層 モデルではバイリニアモデルの結果が提案モデルのそれを上回る。 これまでの検討結果と同様に最上階と最下階で両者の差が顕著であ り、復元力モデルによる高次モードの励起状態の差が原因となって いる傾向が見られる。一方、入力地震動レベルと免震層の最大応答 変位の関係では、両者の差は僅かである。

\section{6. 免震U型ダンパーの復元カモデル \\ 6. 1 復元力特性の検討}

免震U型ダンパーは、U型に加工した圧延鋼材の塑性変形による履 歴吸収エネルギーを利用した免震ダンパーである ${ }^{(3)}$ 。鎆材のサイ ズ、本数を自由に組み合わせることができ、ダンパーの配置を積層 ゴムと一体とする、あるいは別置きにすることで比較的自由な設計 が可能となる利点を有する。ここでは図20に示すNSUD $55 \times 6^{13)}$ と称 するタイプを対象とする。

免震U 型ダンパーに対する(5)〜 (7) 式の提案モデルの適用方法、 ならびに実験結果の回帰分析方法は免震鋼棒ダンパーと同様である。 図21に加力実験 ${ }^{14)}{ }^{15}$ 功得られた荷重変形関係を示す。また、実 験結果を回㷌分析して得られた等価剛性 $K_{e q}$ 、等価粘性减衰定数 $h_{e q}$ 、 荷重切片比 $u$ の実験式を表 4 に示し、 $K_{e q}, h_{e q}$ の回帰状況について 散布データ、回帰式による結果を比較して図 22 に示す。図 21 の実 験結果ではハードニングの傾向が見られることから、これを表現す るために(6)式では $n>1$ となる場合を考慮する。文献 ${ }^{7)}$ を参照して 求めた $n$ の評価式を表 4 に合わせて示す。また、(7)式では $b=0$ とし、 (8) 式か.ら得られるaのみで履歴ループ面積を実験結果と等価にする 条件を満足させる。

バイリニアモデルと提案モデルに対して、加力実験と同じ変形履 歴を与えて得られた解析結果を実験結果と比較して図23に示す。バ イリニアモデルのパラメータは変形量 $400 \mathrm{~mm}$ のときの履歴ループ形 状に合うように設定したものである。雨者を比較すると、提案モデ ルはハードニングの傾向を含め、すべての変形領域で実験結果を良 好に再現していることがわかる。

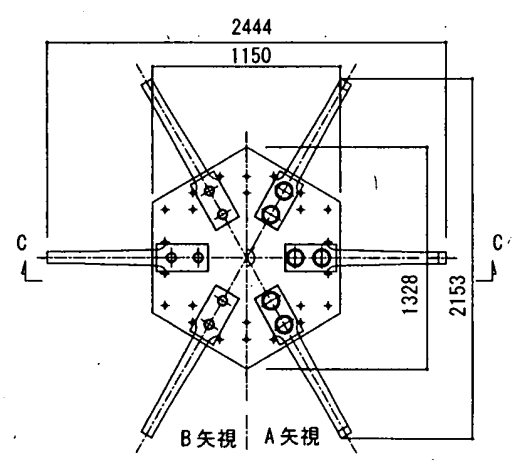

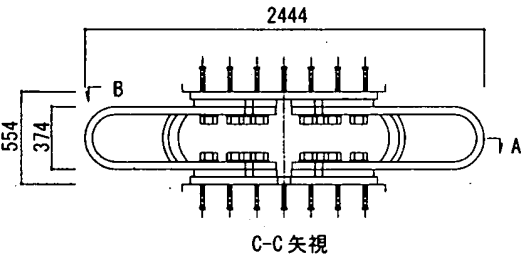

図 20 免震U 型ダンパーの形状 ${ }^{13)}$ (NSUD55 ×6 タイプ)

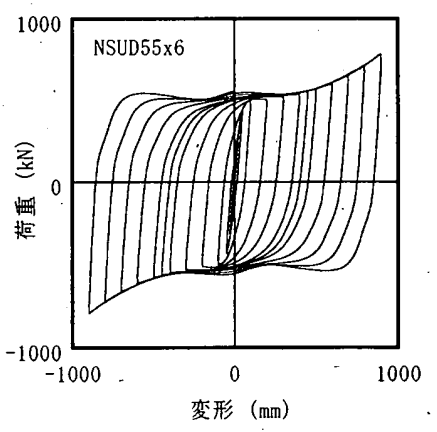

図 21 免震U型ダンパーの実験結果 
表 4 免震U型ダンパーの復元カパラメータ評価式

$\begin{aligned} K_{\text {eq }} & =0.633 X^{-0.856}(\mathrm{MN} / \mathrm{m}) \quad(X \leqq 0.5) \\ & =2.53-3.95 X+2.35 X^{2} \quad(\mathrm{MN} / \mathrm{m}) \quad(0.5<X \leqq 0.9) \\ h_{e q} & =-0.0582+4.22 X-13.7 X^{2}+16.6 X^{3} \quad(X \leqq 0.2) \\ & =0.132+1.65 X-2.47 X^{2}+1.10 X^{3}(0.2<X \leqq 0.9) \\ u & =-0.506+20.6 X-111 X^{2}+214 X^{3}(X \leqq 0.1) \\ & =0.257+5.28 X-14.3 X^{2}+15.6 X^{3}-6.22 X^{4}(0.1<X \leqq 0.9) \\ n & =1.0(X \leqq 0.2) \\ & =12.4 X-1.48(0.2<X \leqq 0.9) \\ & =こ \text { こ } X \text { はダンパーの変形 }(\mathrm{m}) \text { である。 }\end{aligned}$
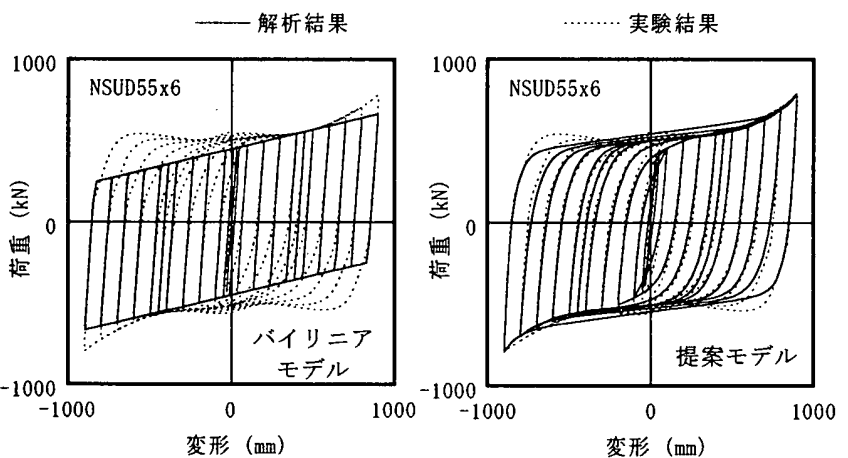

図 23 免震 U 型ダンパーの解析結果

\section{2 地震応答解析による検討}

免震 U 型ダンパーの検討で用いた免震システムは免震鋼棒ダン パーの場合と同様であり、天然ゴム系積層ゴムと図20の免震U型ダ ンパーのみで構成される免震システムを設定した。積層ゴムの形状 と台数、ダンパーの台数は 6 層モデル、12 層モデルとも免震鋼棒ダ ンパーの検討と同一とした。

図 24 に地震応答解析結果を示す。最大応答加速度分布の比較で は、他の免震部材と同様に 6 層モデルでの差はほとんど見られない が、12層モデルではバイリニアモデルの結果が提案モデルのそれを 上回る。やはり最上階と最下階での差が顕著であり、バイリニアモ デルでは高次モードが提案モデルよりも大きく励起される応答加速 度分布となっている。一方、12層モデルにおける入力地震動レベル と免震層の最大応答変位の関係では、入力加速度が200Gal付近でバ イリニアモデルの結果が提案モデルをそれを下回るが、それ以外の 入カレベルでは両者の結果はほぼ同じである。

\section{7. 結論}

本論文では、履歴減衰型免震部材の復元力特性について検討を行 い、共通の数式表現によって荷重変形関係を再現する復元力モデル を提案した。対象とした免震部材は実験データを入手した、低弾性 (G4) タイプの高减衰積層ゴム、鉛プラグ入り積層ゴム、免震鋼棒ダ ンパー、免震U型ダンパーの 4 種類である。この復元力モデルは著 者が G6 タイプの高減衰積層ゴムに対して提案したものであるが ${ }^{2)} 、$ 本論文では他の履歴堿衰型免震部材に対して復元力モデルの抎張を 試みた。高堿衰積層ゴム、免震鎆棒ダンパー、免震U型ダンパーの 3 種類の免震部材については、実験結果より得られた等価剛性（あ るいは等価せん断弾性率)、等価粘性減衰定数、荷重切片比の 3 種類 の指標を用いて復元力特性を評価することによって復元力モデルの 拡張を行った。鉛プラグ入り積層ゴムについては、ゴム径と鉛プラ
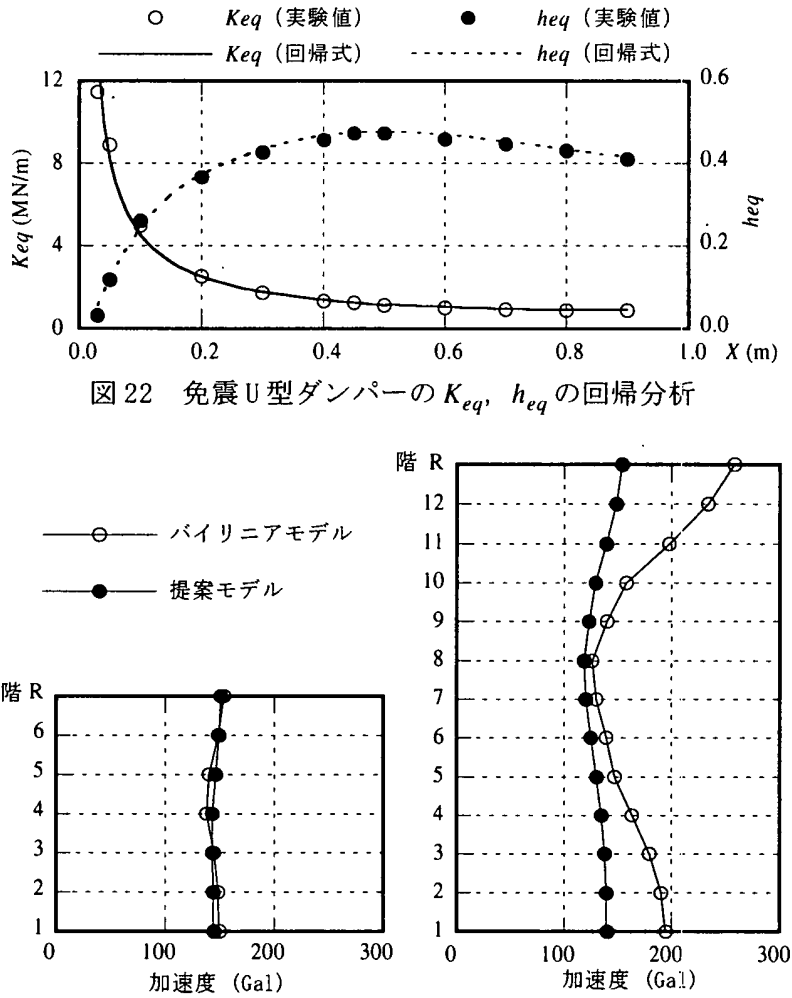

（a）原波形入力時の応答加速度分布

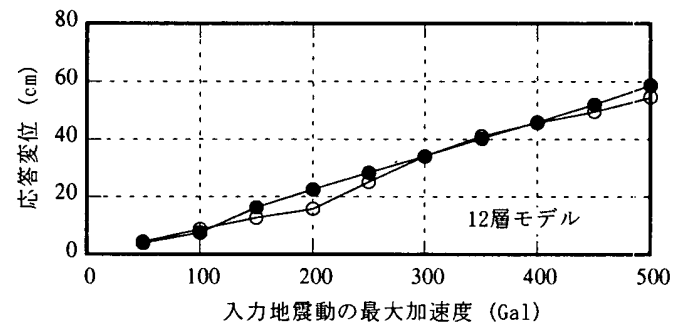

（b） 入力地震動レベルと免震層最大応答変位の関係

図 24 免震鋼棒ダンパーを用いた建物モデルの最大応答值

グ径の任意の組み合わせに対応すべく、従来から用いられている修 正バイリニアモデルのパラメータ評価式を適用し、提案モデルによ る等価粘性減衰定数を修正バイリニアモデルのそれと等価にすると いう仮定を導入することによって復元力モデルを拡張した。

復元力モデルの妥当性を検証するために、免震部材の加力実験よ り得られた荷重変形関係との比較を行った。加力実験と同じ変形履 歴を与えて得られた既往のモデルと提案モデルの各荷重変形関係を 比較した結果、いずれの免震部材についても提案モデルは既往のモ デルよりも実験結果を良好に再現できた。ただし、いずれの検討も 特定の条件下で実施された実験結果を再現し比較したものである。 したがって、本研究で扱った実験条件と異なる状況下でゆ適用に関 しては、条件の相違がもたらす復元力特性の変動の有無凊別途考慮 する必要がある。

続いて、同じ条件下で復元カデータを設定した既往のモデルと提 案モデルによる地震応答值について比較検討を行った。2 種類の免 震建物に対して、上記 4 種類の履歴減衰型免震部材を用いた免震シ ステムを設定した。地震応答解析結果の比較では、提案モデルの方 が既往の復元カモデルよりも小さな最大応答加速度值を与えた。既 
往の復元力モデルは概ね安全側の評価を与えているが、一方で免震 部材の性能を十分に評価していないとも言える。応答值の違いは主 として上部構造の忘答加速度に見られ、特に最下階と最上階に顕著 な差があった。これは、2 次以上の振動モードの励起状態が復元力 モデルによって異なることが原因であると考えられる。

上部構造が十分に剛であり 1 次モードが卓越する場合、上部構造 の高さ方向の応答加速度分布はほぼ一定である ${ }^{16)}$ 。しかし、最近に 見られる高層免震建物や上部構造を鉄骨造とした免震建物の事例か ら判断すると、上部構造の剛性は以前よりも相対的に小さくなる傾 向にある。よって、免震部材の復元力モデルの違いが免震建物の応 答值、特に 2 次以上の振動モードに起因した応答值に及ぼす影響は 一層大きくなると考えられる。したがって、免震部材の復元力特性 の評価、および復元力モデルの適用には十分な配慮が必要となる。

\section{謝辞}

本研究を遂行するにあたり、東洋ゴム工業株式会社、オイレスエ 業株式会社、株式会社巴コーポレーション、新日本製鐵株式会社よ り免震部材の実験データならびに貴重な助言を頂きました。また、 地震応答解析は清水建設株式会社開発の 3 次元非線形振動解析シス テムDAC3Ǹ を使用しました。関係各位に感謝の意を表します。

\section{参考文献}

1）（財）日本免震構造協会：免震構造入門

2) M.Kikuchi and I.D.Aiken:An analytical hysteresis model for elastomeric seismic isolation bearings, Earthquake Engineering and Structural Dynamics, Vol. 26, 215-231, 1997.

3）菊地優，北村佳久，太田雅己:鉛ブラグ入り樌層ゴムの復元力特性に関す る一考察(その $1 ， 2$ )，日本建築学会大会学術講演梗概集，583-586，1999 年

4）菊地優:免震鋼棒ダンパーの復元カモデルに関する研究，日本建築学会大 会学術講演梗概集，673-674，2000年

5）㐘地優, 吉川秀昭: 免震U型ダンパーの復元カモデルに関する研究, 日本 建築学会大会学衍講演梗概集，515-516，2002年

6）東洋ゴム工業（株）：免震用積層ゴム（G=4）技術資料，平成 9 年

7）㐘地優：免震構造物の地震時損傷度評洒法に関する研究, IRI 研究報告, 95-03，1995年

8）（財）日本免震構造協会 : 免震部材標準品リスト，2001年

9）オイレス工業（株）:LRB技術資料，2000年 6 月

10）オイレス工業（株）：LRB技術データ集CD-ROM版 Ver. 1.1，2000年

11）(株）巴コーポレーション：免震鋼棒ダンパー，2000年

12）岡本哲美, 玉淞健一郎, 高瀬恵悟, 士師利昭, 島貫貴志: 免震鋼棒ダンパー \$90R365 の性能確認試験（その1), 日本建築学会大会学術講演梗概集， 2000 年, $667-668$

13）新日本製鐵（株）：免震U型ダンパー技術資料，平成 12 年 12 月

14）鈴木一弁, 吉川英章, 佐伯英一郎, 渡辺厚: 免震U型ダンパーに関する実 験的研究 (その1，2), 日本建築学会大会学術講演梗概集，665-668，1999 年

15）鈴木一弁, 渡辺厚, 吉川英章, 小西宏明, 高山峯夫: 免震U型ダンパーに 関する実験的研究 (その $3 \sim 6$ ), 日本建築学会大会学術講演梗概集, 659666,2000 年

16) J.M. Kelly : Earthquake-resistant design with rubber, Springer, 1997.

\section{付録 提案モデルのパラメータの数值变化}

復元力モデルの荷重変形関係を表現する $(5)$ (7) 式に関して、履 歴ループの形状を操作する各パラメータのうち、初めに $a$ を履歴 ループ面積を等価にする条件のもとに (8) 式より決定するが、これを をaについて代数的に解くことはできない。したがって、Newton法
を用いて数值的に求める必要がある。通常は陽な形で現れないパラ メータであるが、付図 1 に各免震部材における $a$ の具体的な数値の 変化を示す。なお、各免震部材の実験式の変数の違いにより、高減 衰積層ゴムと鉛プラグ入り積層ゴムはせん断ひずみに対する值とし て付図 1 (a)に、免震鋼棒ダンパーと免震U型ダンパーは変形に対す る值として付図 1 (b)に分けて図示した。

高減衰積層ゴムについては、修正バイリニアモデルの初期剛性 $K_{1}$ の変化と同様に、初期剛性に大きく影響する $a$ がせん断ひずみ 1.5 を越えるあたりから、付図1（a）の太破線部分のように急激に增大す る傾向がある。これは $a \rightarrow \infty$ としても所要の履歴ループ面積を確保 できないことが原因であり、提案モデルではパラメータ $b$ にる履 歴ループ面積を付与することでこれを解決している。本論文で適用 した高减衰積層ゴムについては、せん断ひずみ 1.5 を越える時点に おいて $a$ を固定（ $\gamma=1.5$ で $a=8.26 ）$ とし、パラメータ $b$ にって履 歴ループ面積を等価とした。同図では、 $a$ について採用した部分を 太実線で表現している。また、付図 1（a)にはせん断ひずみ1.5以上 において (9) 式によって計算されるbを合わせて示している。鉛プラ グ入り積層ゴムについては、 $a$ はほぼ直線的に増大しており著しい 増加とならないことから、パラメータbによる履歴ループ.面積の付 与は必要としない。免震鋼棒ダンパーに関しても鉛プラグ入り積層 ゴムと同様である。免震U型ダンパーについては変形が $80 \mathrm{~cm}$ を越え るあたりから $a$ が急激に增大する傾向が見られるものの、この変形 が非常に大きな領域であることから

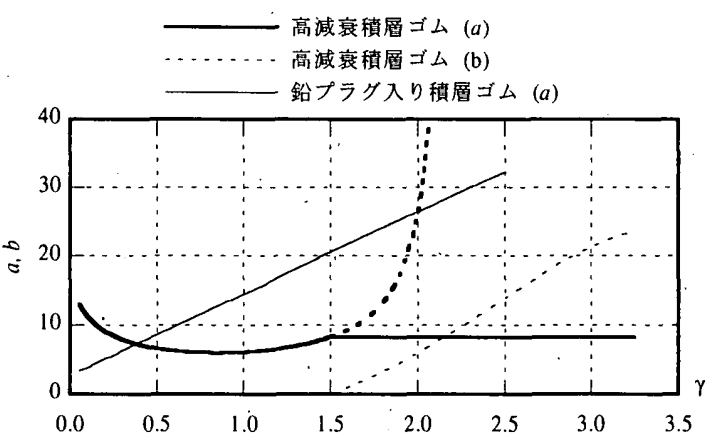

（a） 高煘衰積層ゴム，鉛プラグ入り積層ゴムの場合

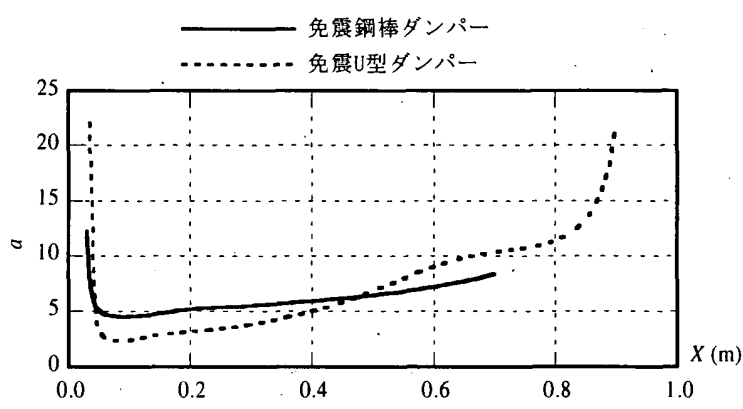

（b）免震鋼棒ダンパー，免震U 型ダンパーの場合 付図 1 復元力モデルのパラメータの変化 （2002年 9 月 6 日原稿受理，2002年12月 27 日採用決定） 